\title{
ISOLASI SENYAWA AKTIF FLAVONOID RUTIN MADU SEBAGAI METABOLIT SEKUNDER BAHAN BAKU PENGEMBANGAN OBAT DIABETES MELITUS
}

\section{ISOLATION OF ACTIVE FLAVONOID COMPOUND FROM HONEY AS A SECONDARY METABOLITE RAW OF DIABETES MELLITUS DRUG}

\author{
Iis Inayati Rakhmat ${ }^{1}$, Euis Reni Yuslianti ${ }^{1}$, Fikri Alatas ${ }^{2}$ \\ ${ }^{1}$ Fakultas Kedokteran Universitas Jenderal Achmad Yani, \\ Jl. Terusan Jenderal Sudirman Cimahi. \\ ${ }^{2}$ Fakultas Farmasi Universitas Jenderal Achmad Yani, \\ Jl. Terusan Jenderal Sudirman Cimahi.
}

Submitted : 13 Juni 2020 Reviewed : 11 Agustus 2020 Accepted : 21 September 2020

\begin{abstract}
ABSTRAK
Metabolit sekunder sebagai bahan baku pengembangan obat modern dibutuhkan terutama untuk penyakit kronis diantaranya diabetes melitus. Bahan alami berpotensi sebagai antidiabetes adalah madu rambutan yang mengandung flavonoid rutin dan diduga mampu melindungi sel beta pankreas dengan mengurangi stres oksidatif. Penelitian ini bertujuan mengisolasi komponen aktif flavonoid (rutin) dari madu rambutan sebagai bahan baku untuk pengembangan obat diabetes melitus. Penyiapan isolat dilakukan dengan mengekstraksi caircair madu diikuti dengan memfraksinasi dengan masing-masing pelarut air, n-heksana, dan etil asetat. Hasil fraksinasi dianalisis dengan kromatografi lapis tipis(KLT) pada plat prasalut Kiesel gel GF254. KLT preparatif dilakukan terhadap fraksi etil asetat menggunakan Plat Preparatif silica gel 60 GF254. Kemurnian Isolat diuji dengan KLT dua arah dengan menggunakan rutin trihidrat sebagai pembanding. Pola-pola kromatogram menunjukkan bahwa bercak senyawa hanya terdapat pada fraksi etil asetat. Hasil kromatogram uji kemurnian menunjukkan ada satu bercak di pengembangan pertama dan pengembangan kedua yang mengindikasikan bahwa isolat adalah senyawa murni rutin yang identik dengan pembanding.
\end{abstract}

Kata kunci : isolasi flavonoid rutin, diabetes melitus, madu

\begin{abstract}
The secondary metabolites as raw material for modern drug development, are needed, especially for chronic diseases, including diabetes mellitus. Diabetes mellitus is a metabolic disease characterized by hyperglycemia. A potential antidiabetic natural ingredient is rambutan honey containing common flavonoids and thought to protect pancreatic beta cells by reducing oxidative stress. This study aimed to isolate the active flavonoid compound (rutin) from rambutan honey as a raw material for developing diabetes mellitus drugs. Preparation of isolates carried out by extracting liquid-liquid honey followed by fractionating with each water, n-hexane, and ethyl acetate solvents. The fractionation results were analyzed by thinlayer chromatography (TLC) on the GF254 Kiesel gel pretalut plate. Preparative TLC was carried out on the ethyl acetate fraction using a silica gel 60 GF254 of Preparative Plate. The isolate purity was tested by bidirectional TLC using rutin trihydrate as a reference.
\end{abstract}


Chromatogram patterns show that compound spots were only present in the ethyl acetate fraction. The results of the chromatogram of the purity test showed that there was one spot in the first and second developments which indicated that the isolate was a pure compound of rutin that was identical to the reference.

Keywords: flavonoid, isolation, diabetes mellitus, honey

\section{Penulis korespondensi:}

Euis Reni Yuslianti

Fakultas Kedokteran Universitas Jenderal Achmad Yani

Email: ery.unjani@yahoo.co.id

\section{PENDAHULUAN}

Diabetes melitus adalah salah satu penyakit metabolik yang ditandai dengan terjadinya hiperglikemia. Hiperglikemia terjadi apabila didapatkan kadar glukosa darah puasa $\geq 126$ $\mathrm{mg} / \mathrm{dL}$ atau gula darah 2 jam setelah makan $\geq 200 \mathrm{mg} / \mathrm{dL}$ (ADA, 2014). Pada pasien diabetes melitus, kenaikan glukosa darah dapat terjadi akibat kekurangan sekresi insulin, kerja insulin yang menurun, atau keduanya. dari diabetes melitus adalah sering kencing (poliuri) di malam hari, rasa haus yang berlebihan (polidipsi), sering merasa lapar (polifagi), berat badan yang menurun dengan cepat, keluhan lemah badan, kesemutan pada tangan dan kaki, gatal-gatal (pruritus), luka sulit sembuh, dan buram (Powers, 2012; Kemenkes RI, 2013). Diabetes melitus menimbulkan sindrom metabolik, selain kelainan metabolisme karbohidrat dapat melibatkan kelainan dan gangguan metabolisme lipid serta nuleotida purin penghasil asam urat. Sindrom metabolik ini selain menimbulkan efek hipergikemi dapat mengakibatkan dislipidemia dan hiperurikemia. Bahaya yang dapat ditimbulkan pada diabetes melitus jangka panjang adalah kehilangan penglihatan, gagal ginjal akibat nefropati, dan neuropati (ADA, 2014)

Penduduk yang mengalami penyakit diabetes melitus di dunia sampai tahun 2014 telah terdapat 347 juta dan 80 persen kasus terdapat di negara berkembang. Pada tahun 2012, sekitar 1,5 juta orang meninggal akibat penyakit diabetes dan diperkirakan pada tahun 2030 jumlah kematian akibat diabetes akan meningkat sampai dua kali lipat (WHO, 2015). Hasil Riset Kesehatan Dasar (Riskesdas) tahun 2013 menyatakan bahwa proporsi penyakit diabetes melitus pada penduduk usia diatas 15 tahun di Indonesia sebesar 6,9\% dan diperkirakan jumlah penderita yang menderita penyakit tersebut sekitar 12 juta orang. Dari $6,9 \%$ penderita diabetes melitus yang didapatkan, 30,4\% telah terdiagnosis sebelumnya, sedangkan 69,6\% tidak terdiagnosis sebelumnya (Kemenkes RI, 2013). Diabetes melitus dikenal sebagai silent killer karena sering tidak disadari oleh penyandangnya dan saat diketahui sudah terjadi komplikasi (Purnamasari, 2010). Jika dibandingkan antara penduduk perkotaan dan pedesaan, ternyata proporsi di pedesaan tidak lagi lebih rendah dibandingkan di perkotaan (Kemenkes RI, 2013).

Diabetes melitus membutuhkan pengobatan baik secara nonfarmakologi dan farmakologi yaitu berupa oral maupun parenteral. Obat antidiabetes oral diantaranya golongan tiazolidinedion seperti glitazon, golongan sekretagok insulin seperti tolbutamid dan glibenklamid, dan penghambat alfa glukosidase seperti akarbose. Pada beberapa kondisi dislipidemia dan hiperurikemia diperlukan pengobatan lain penderita diabetes melitus diantaranya golongan simvastatin dan alopurinol. Pengobatan tersebut memiliki banyak efek samping, diantaranya asidosis laktat, gangguan pencernaan, penambahan berat badan, dan gangguan enzim hati. Selain itu pengobatan diabetes relatif mahal, sehingga banyak pasien yang mencoba pengobatan tradisional (Purnamasari, 2010; Suharti, 2009).

Mekanisme kerja tanaman yang berkhasiat sebagai antidiabetes, antara lain penghambat enzim $\alpha$-glukosidase, perbaikan fungsi hormone insulin, dan perangsangan kelenjar pankreas 
telah banyak diteliti,, serta sebagai antioksidan kuat pada jalur poliol pathway diabetes melitus. Mekanisme kerja sebagai antidiabetes pada tanaman sangat variatif. Pinus desiflora Aloe vera, dan tiga spesies Salacia bekerja dengan menghambat enzim $\alpha$-glukosidase, Allium sp, Tinospora crispa dan Scoporia dulcis bekerja dengan menginduksi kelenjar pankreas dalam menghasilkan insulin, sedangkan Androgaphis paniculata dan Ipomeae batatas bekerja dengan memulihkan fungsi hormon insulin. Ekstrak daun mengkudu (Morinda citrifolia) memiliki kerja sebagai inhibitor $\alpha$-glukosidase dan memperlambat absorpsi glukosa. Ekstrak bunga delima (Punica granatum) memiliki kerja sebagai inhibitor $\alpha$-glukosidase dan peningkatan reseptor Insulin (Subroto, 2006).

Madu monofloral yaitu madu rambutan diketahui mengandung flavonoid yang merupakan senyawa golongan polifenol yang terdistribusi luas pada tumbuhan dalam bentuk glikosida yang berkaitan dengan suatu gula, karena itu flavonoid merupakan senyawa yang bersifat polar. Flavonoid rutin yang melindungi sel beta pankreas dengan mengurangi stres oksidatif, sedangkan kandungan fruktosa merangsang pengeluaran insulin dan mengaktivasi enzim glukokinase yang merangsang metabolisme glukosa dan mengubah glukosa menjadi glukosa 6fosfat sehingga glukosa darah menurun, maka dari itu madu diduga cocok dalam membantu menurunkan kadar glukosa darah pasien diabetes melitus tipe 1 maupun tipe 2 (Yuslianti, 2014). Obat tradisional/obat bahan alam asli Indonesia yang mudah didapat, enak, dan murah di atas dikenal dimasyarakat sebagai bahan antioksidan tinggi dapat membantu penatalaksanaan diabetes melitus.

Hasil penelitian pada tahap awal pada tikus diabetes melitus tipe II yang diinduksi oleh streptozotosin didapatkan bahwa madu rambutan dapat menurunkan $500 \mathrm{mg} / \mathrm{kgBB}$ sebesar $42,4 \mathrm{mg} / \mathrm{dL}$ dan menurunkan kadar kolesterol darah sebesar 30,78 mg/dl (Rakhmat, 2017) . Khasiat madu rambutan sebagai obat diabetes melitus telah dikenal namun belum diketahui dan diteliti kandungan zat aktif yang terkandung didalamnya sehingga studi bahan alam tersebut masih sangat terbuka luas. Berdasarkan hal tersebut maka tujuan penelitian ini adalah mengisolasi komponen aktif flavonoid yaitu rutin dari madu rambutan sebagai bahan baku untuk pengembangan obat diabetes melitus sehingga diharapkan akan didapat suatu isolat zat aktif dari metabolit sekunder hasil alam Indonesia yang bermanfaat untuk masyarakat.

\section{METODE PENELITIAN}

\section{Alat dan Bahan}

Alat dalam penelitian ini diantaranya corong pisah, beaker glass, erlenmeyer, pelarut, statif dan ring, rotary evaporator, gelas ukur, chamber, fase diam (plat prasalut), fase gerak (pengembang hexan, etilasetat), pipa kapiler, plat preparatif 60 GF254, silica gel 60, plat kaca ukuran $20 \mathrm{~cm}$ x $20 \mathrm{~cm}$, alat pembuat plat merek camag, pipa kapiler, chamber ukuran $30 \mathrm{~cm} \mathrm{x}$ $30 \mathrm{~cm}$, gelas ukur, erlenmeyer, plat prasalut Kieselgel GF254.

Bahan dalam penelitian ini adalah madu rambutan berupa cairan 500 gram, akuades, pelarut n-hexan, pelarut etil asetat, fraksi etil asetat, pembanding rutin trihidrate. Madu diambil dari hasil lebah Apis mellifera dari Peternakan Lebah Pusbahnas Cijunti Cikopo Cikampek Jawa Barat sebanyak satu kotak sarang.

\section{Prosedur Kerja}

Madu diekstraksi cair kemudian difraksinasi air, n-heksana, dan etil asetat. Sebanyak 100 gram madu dilarutkan dalam air sebanyak $300 \mathrm{ml}$ dan dimasukkan kedalam corong pisah, ditambahkan pelarut $n$-heksana ke dalam corong pisah dengan perbandingan volume sama 
banyak. Selanjutnya dikocok atau digoyangkan corong pisah dan didiamkan sampai larutan dalam corong memisah.

Larutan fasa n-heksana akan berada di lapisan atas dan larutan madu dalam fasa air di lapisan bawah, setelah memisah dikeluarkan larutan madu dan ditampung dalam beaker glass selanjutnya dikeluarkan larutan fasa n-heksana dan ditampung dalam wadah yang berbeda. Langkah proses ekstraksi di atas dilakukan secara berulang hingga tidak ada lagi senyawa yang tersisa di fasa $n$-heksana yang ditunjukkan dengan fasa n-heksana sudah tidak berwarna lagi. Selanjutnya dilakukan fraksinasi larutan madu dalam air menggunakan pelarut etilasetat dengan memasukkan larutan madu tadi ke dalam corong pisah, ditambahkan pelarut etilasetat dengan volume yang sama dengan volume larutan madu, dikocok dan dibiarkan memisah. Fraksi etil asetat dan fraksi air dipisahkan. Hasil proses ekstraksi dan fraksinasi ini diperoleh tiga fasa larutan, yaitu fraksi encer n-heksana, fraksi etilasetat dan fraksi air. Masing-masing fraksi encer di pekatkan menggunakan rotary evaporator hingga diperoleh tiga fraksi pekat (Gritter, 1991; Stahl, 1985).

Hasil fraksinasi dianalisis dengan kromatografi lapis tipis (KLT) pada plat prasalut Kiesel gel GF254. Masing-masing fraksi diteteskan pada plat dengan jarak antar tetesan dari pinggir plat $1 \mathrm{~cm}$, jarak dari bawah plat $1 \mathrm{~cm}$, dan batas akhir pengembangan $1 \mathrm{~cm}$ dari batas atas plat. Dari hasil kromatografi lapis tipis didapatkan pola kromatogram fraksi hexan tidak terdapat noda senyawa apapun begitu juga di fraksi air madu tidak terdapat noda semua senyawa ngumpul di fraksi etil asetat dengan demikian senyawa rutin kemungkinan besar ada di fraksi etil asetat. Penekanan untuk tahap isolasi berikut akan diarahkan pada fraksi etil asetat yang menunjukkan noda senyawa yang terkumpul. (Gritter, 1991; Stahl, 1985).

KLT preparatif dilakukan pada fraksi etil asetat hasil fraksinasi menggunakan Plat Preparatif 60 GF254. Plat Preparatif menggunakan alat pembuat plat Camag dengan ketebalan plat 500 ul, setelah plat kering, sampel ditotolkan memanjang pada plat dari ujung hingga ke ujung plat dengan jarak dari bawah $1 \mathrm{~cm}$, diulangi penotolan sampel 2 atau 3 kali dan biarkan sampel kering. Plat dimasukkan ke dalam chamber yang telah diisi dengan fase gerak $\mathrm{n}$ heksana : etil asetat (1:1), dibiarkan pelarut merambat ke atas sampai dengan batas akhir pengembangan, yaitu ujung plat, dikeluarkan plat dari chamber dan pantau di bawah lampu UV366. Noda memanjang berfluorensi biru ditandai, selanjutnya kerok noda yang telah ditandai dan kumpulkan hasil kerokan. Hasil kerokan masukan dalam kolom yang telah di isi kapas dibawah kolom dan elusi dengan menggunakan pelarut etil asetat. Hasil Elusi disebut Isolat atau senyawa murni dan dipantau menggunakan Kromatografi Lapis Tipis dan pembanding rutin trihidrat (Stahl, 1985). Kemurnian isolat diuji dengan KLT dua arah yaitu, Pengembang pertama, yaitu campuran n-heksana : etil asetat (1:1) dan pengembang kedua, yaitu campuran kloroform : aseton (9:1).

\section{Analisis Data}

Analisis data dalam penelitian ini dilakukan melalui analisis univariat. Isolasi senyawa aktif menggunakan analisis univariat. Semua data disimpan dalam bentuk arsip digital komputer. 


\section{HASIL DAN PEMBAHASAN}

\section{Ekstraksi Cair-cair( Fraksinasi)}

Fraksinasi adalah suatu proses pemisahan satu atau lebih senyawa berdasarkan tingkat polaritas atau proses pemisahan suatu zat dari campuran zatnya. Ekstraksi cair-cair bertujuan untuk memisahkan senyawa berdasarkan polaritas pelarut dari mulai non polar, semi polar dan polar. Fraksinasi umumnya dimulai dari pelarut non polar selanjutnya dengan pelarut semi polar dan pelarut polar. Tahapan fraksinasi bertingkat dengan menggunakan pelarut h-heksana. Gambar 1A menunjukkan pemisahan pada corong pisah antara fasa n-heksan (bagian atas) dan fasa air (bagian bawah), dimana fasa air larutan madu berwarna kuning, sedangkan pada fasa nheksan tidak berwarna (jernih). Hal ini menunjukkan bahwa senyawa yang bersipat non polar pada madu akan tertarik oleh pelarut yang non polar (n-heksana), sedangkan senyawa polar akan tertarik ke dalam pelarut polar (air). Gambar 1B menunjukkan pemisahan pada corong pisah antara fraksi air (bagian bawah) dan fraksi etil asetat (bagian atas), dimana pada fraksi etil asetat berwarna kuning dan lebih jernih. Hal ini menunjukkan, bahwa ada senyawa yang sebelumnya banyak tertarik di fasa air (polar) pada ekstraksi pertama, namun pada fraksinasi dengan etil asetat banyak ada yang tertarik ke fraksi etil asetat (semi polar).

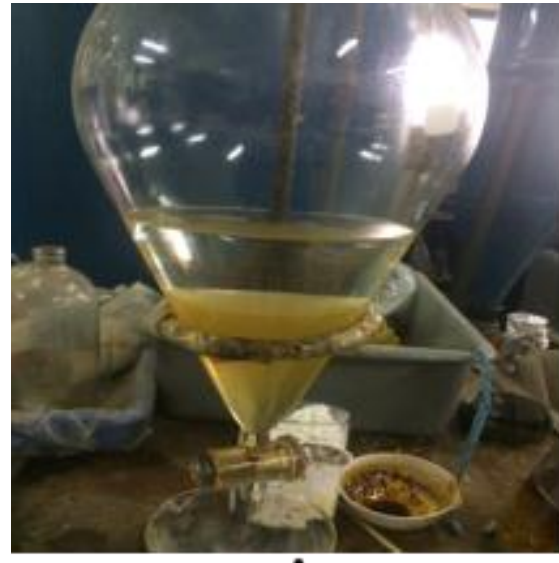

A

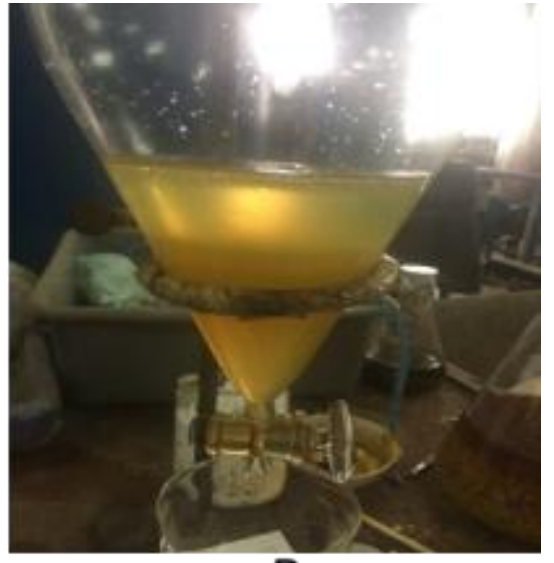

B

Gambar 1. Hasil fraksinasi madu dengan pelarut (A) n-heksana dan (B) etil asetat

\section{Kromatograpi Lapis Tipis (KLT)}

Hasil fraksinasi dipantau dengan dilakukan pada plat prasalut Kiesel gel GF 254 (E.Merck) dengan sistem pengembangan campuran n-heksan : Etilasetat (1:1) dan penampak bercak lampu UV 366

Hasil kromatografi lapis tipis fraksi n-heksana, etil asetat, dan air seperti ditampilkan pada Gambar 1, menunjukkan pada fraksi n-heksana dan fraksi air tidak terdapat bercak senyawa apapun, namun pada fraksi etil asetat, tampak ada bercak yang cukup tebal. Hal ini bisa mengindikasikan senyawa rutin kemungkinan besar berada pada fraksi etil asetat. Sehingga pada penelitian lebih lanjut dilakukan tahap isolasi hanya pada fraksi etil asetat. 


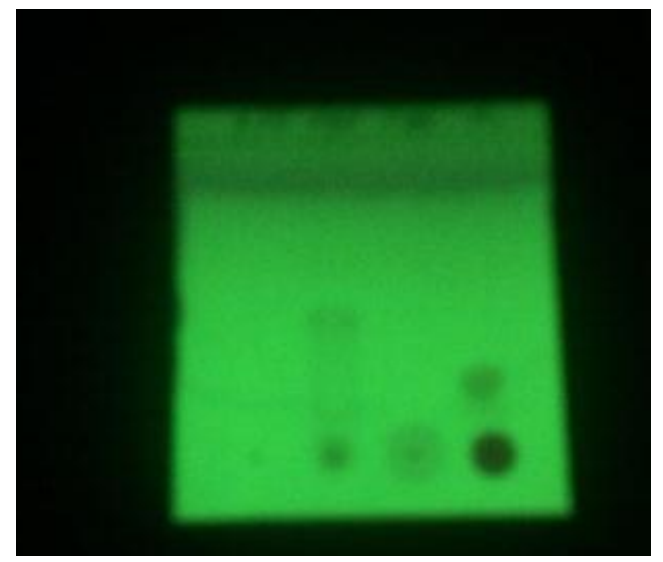

Gambar 2 Kromatogram hasil fraksinasi

Keterangan dari kiri ke kanan: fraksi hexan, fraksi etil asetat, fraksi air madu, pembanding

\section{Kromatografi Lapis Tipis Preparatif}

Hasil kromatografi lapis tipis preparatif pada fraksi etil asetat menggunakan Plat Preparatif 60 GF254 dan sistem pengembangan n-heksana : etil asetat (1:1) ditampilkan pada Gambar 3.

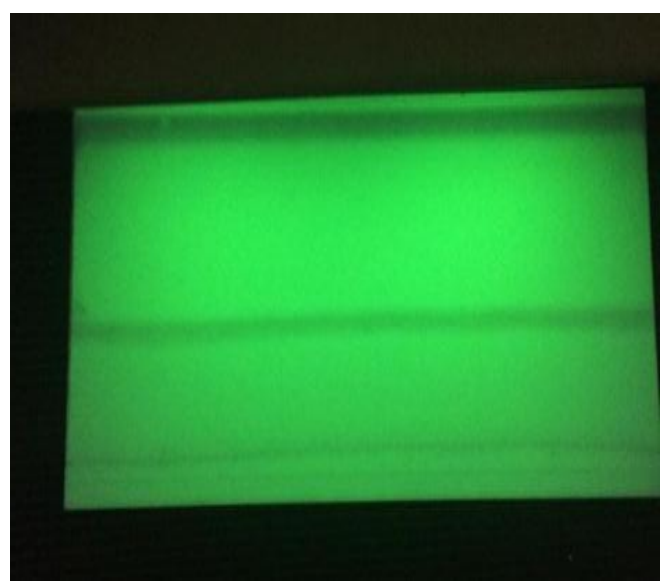

Gambar 3 Kromatogram lapis tipis preparatif dari fraksi etil asetat

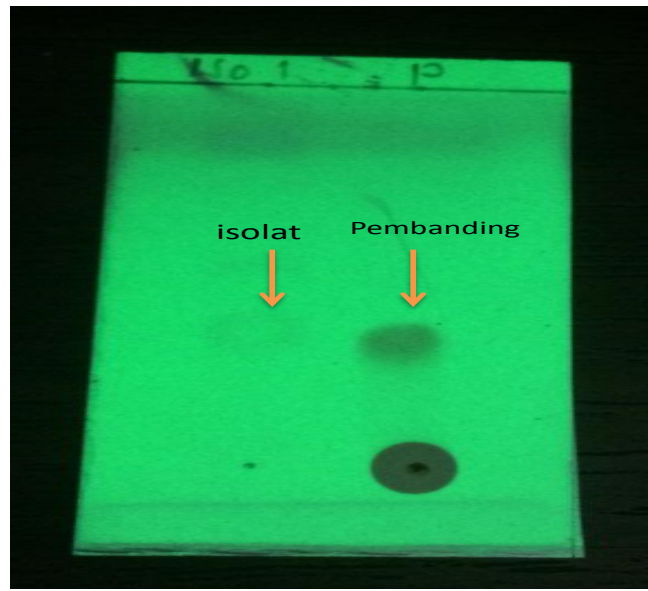

Gambar 4. Kromatogram isolat (kiri) dan pembanding rutin trihidrat (kanan) 
Hasil perhitungan nilai $\mathrm{Rf}$ bercak isolat dan pembanding rutin trihidrat pada kromatogram yang ditampilkan pada Gambar 4, menunjukkan nilai Rf yang sama yaitu 0,39. Hal ini menunjukkan bahwa isolate memamng benar adalah suatu glikosida, yaitu rutin.

\section{Uji Kemurnian Senyawa Isolat}

Untuk mengetahui kemurnian Isolat dilakukan KLT dua arah menggunakan 2 sistem pengembangan yang berbeda yaitu, pengembang pertama campuran n-heksana : etil asetat (1:1) dan pengembang kedua campuran kloroform : aseton (9:1). Hasil kromatogram uji kemurnian pada Gambar 5 menunjukkan hanya ada satu noda di pengembangan pertama dan pengembangan kedua yang dapat diartikan bahwa isolat yang diperoleh adalah senyawa murni yang identik dengan pembanding rutin trihidrat.

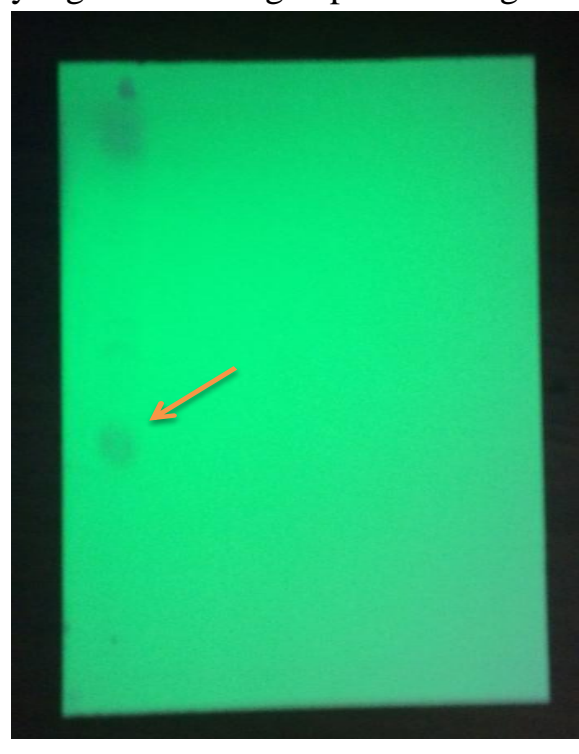

A

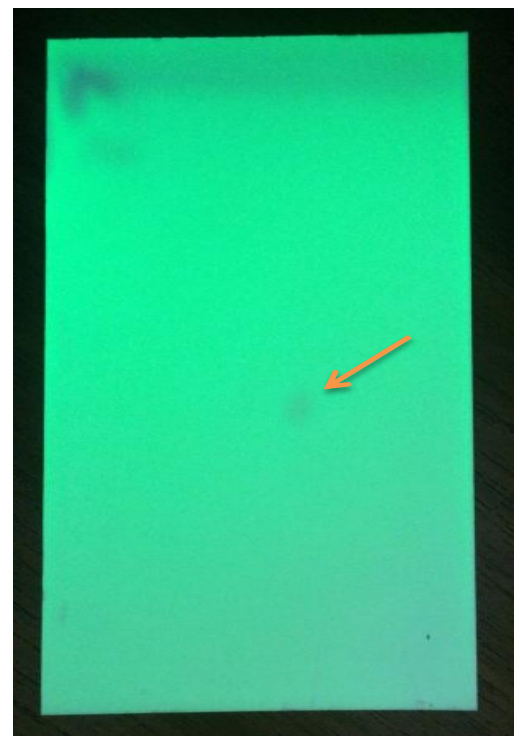

B

Gambar 5. Kromatogram KLT dua arah dengan (A) pengembang pertama campuran n-heksana : etil asetat (1:1) dan (B) pengembang kedua campuran kloroform : aseton (9:1).

\section{KESIMPULAN}

Berdasarkan hasil fraksinasi dan analisis dengan kromatografi lapis tipis menunjukkan bahwa hasil isolasi zat aktif senyawa rutin dari madu terdapat hanya pada fraksi etil asetat. Hasil kromatografi lapis tipis pada plat Prasalut Kiesel gel GF25 dengan sistem pengembangan-heksana:etil asetat (1:1) dan penampak bercak lampu UV366 menunjukkan bercak hasil isolasi identik dengan pembanding rutin tridhidrat. Uji kemurnian senyawa rutin pada hasil isolasi yang dilakukan dengan KLT dua arah menggunakan sistem pengembangan pertama n-heksana-etil asetat (1:1) dan pengembang kedua kloroform-aseton (9:1) dan penampak bercak lampu UV366 menunjukkan isolat adalah murni hanya rutin.

\section{UCAPAN TERIMAKASIH}

Ucapan terima kasih tim peneliti ucapkan untuk pihak LPPM Unjani yang berkontribusi terhadap pelaksanaan penelitian ini. 


\section{DAFTAR PUSTAKA}

American Diabetes Association (ADA). 2014. Standards of medical care in diabetes mellitus. ADA. Amerika.

Gritter, R.J., James, M., Bobbitt, A.E., Schwarting. 1991. Pengantar Kromatografi, edisi kedua, Penerbit ITB Bandung.

Harborne, J., B. 1987. Metode Fitokimia. Penuntun cara modern menganalisis tumbuhan. Terjemahan Kosasih Padmawinata. Bandung; Penerbit ITB.

Harborne, J.B., 1996. Metode fitokimikia Penuntun cara modern menganalisis tumbuhan. Penerbit ITB. Bandung. 9, 13-14.

Kementrian Kesehatan Republik Indonesia (Kemenkes RI). 2013. Hasil riset kesehatan dasar (riskesdas)

http://www.litbang.depkes.go.id/sites/download/materi_pertemuan/launch_riskesdas/Ris kesdas\%20Launching\%20Kabadan.pdf..

Powers, A.C., Longo., D.L., Fauci, A.S., Kasper, D.L., dan Hauser, S.L. 2012. Powers AC. Diabetes mellitus. Harrison's principles of internal medicine. United States of America: The McGraw-Hill Companies, Inc; 18: 2968-3003.

Purnamasari, D., Sudoyo, A.W., Setiyohadi, B., Alwi, I., Simadibrata, K.M., dan Setiadi, S. 2010. Diagnosis dan klasifikasi diabetes melitus. Buku ajar ilmu penyakit dalam. Jakarta Pusat: Interna Publishing. 5: 1880-2.

Rakhmat, I.I., Yuslianti, E.R., Koswara, T. 2017. Antihyperglycemic Effect of Rambutan Honey in Alloxan-Induced Diabetic Wistar Rats. Journal Pharmacology and Toxicology. 12(1):42-49.

Stahl, E. 1985. Analisis Obat Secara Kromatografi dan Mikroskopis.Penerbit ITB Bandung.

Suharti, K.S., Gunawan., dan Sulistia. 2009. Insulin dan antidiabetik oral. Farmakologi dan terapi. Jakarta. Departemen Farmakologi dan Turapetik Fakultas Kedokteran Universitas Indonesia. 5: 481-95.

Subroto, A.M. 2006. Ramuan Herbal Untuk Diabetes Melitus. Penebar Swadaya. Jakarta. 3254.

World Health Organization (WHO). 2015. Diabetes. WHO. Geneva.

Yuslianti, E.R. 2014. Antioxidant Activity of Rambutan Honey in Preventing Lipid Peroxidation. IADR-SEEADE $28^{\text {th }}$ Annual Scientific Meeting. Revolutionising Education. Community Growth Through Research. Programme Book. Kuching Sarawak Malaysia. 125. 